\title{
Reconstruction of Advocate Policy in Assisting Child Cases Based on Value of Justice (A Study in Kuningan District)
}

\author{
Diding Rahmat \\ Faculty of Law, University of Kuningan, Indonesia \\ Doctoral Program of Legal Studies, Sultan Agung Islamic University, Indonesia \\ E-mail : didingrahmat@uniku.ac.id \\ Teguh Prasetyo \\ Faculty of Law, University of Setya Wacana, Indonesia \\ Sri Endah Wahyuningsih \\ Doctoral Program of Legal Studies, Sultan Agung Islamic University, Indonesia
}

How to cite : Rahmat, Diding; Teguh Prasetyo; Sri Endah Wahyuningsih. (2018). Recontuction of Advocate Policy in Assisting Child Cases Based on Value of Justice (A Study in Kuningan District) . UNIFIKASI : Jurnal Ilmu Hukum, 5(2), 85-95.

DOI : 10.25134/unifikasi.v5i2.1222

Submitted : 24-05-2018 Revised : 15-08-2018 Accepted : 29-08-2018

\begin{abstract}
An advocate is a person whose profession is providing legal services both inside and outside the court that meets the requirements based on legislations. In child cases, the role of advocates is needed to provide legal protection for children in order to create a child generation which is free from discrimination, violence and exploitation. The purpose of this research is to analyze various regulations regarding advocate policy in legal assistance on criminal cases, especially on child cases and how the policy is implemented in assisting child cases at the level of investigations in police, prosecutor's office and court in Kuningan District. The method used in this research was the Evaluative Analysis method, which is a method of collecting and presenting the obtained data to analyze actual situation and subsequently carry out rational analysis based on juridical references through library and field research. As results, this research found that the regulations applied in providing legal assistance on child cases include; Article 23 paragraph (1) of Law Number 11 of 2012 concerning System of Child Criminal Justice, and Kuningan District Regulation Article 17 Point (b) Number 15 of 2003 concerning Implementation of Child Protection. Moreover, the implementation of advocate policy in assisting child cases in Indonesia has not been carried out optimally both in police, prosecutor's office and court due to the following factors, namely legislation factors, legal apparatus factors, and society awareness factors (legal culture). Therefore, there is a need for reconstruction of legal awareness through education, training and socialization, especially for the law enforcement of child cases. Besides, the society's legal culture regarding the obligation of advocate assistance needs to be improved so that the objectives to provide child protection can be achieved.
\end{abstract}

Keywords: Advocate, Child Protection, Justice

\section{Rekontruksi Kebijakan Advokat dalam Pendampingan Perkara Anak Berbasis Nilai Keadilan (Studi di Kabupaten Kuningan)}

\begin{abstract}
Abstrak : Advokat adalah orang yang berprofesi memberi jasa hukum baik didalam maupun di luar pengadilan yang memenuhi persyaratan berdasarkan peraturan per Undang Undang. Dalam perkara anak peran advokat sangat di perlukan dalam perlindungan hukum bagi anak yang merupakan bagian terpenting dalam menjaga generasi anak yang bebas dari diskriminasi, kekerasan dan eksploitasi sehingga mampu membangun generasi anak bahagia dan sejahtera. Tujuan penelitian ini adalah untuk mengetahui perbagai peraturan mengenai kebijakan advokat dalam pendampingan hukum dalam perkara pidana khususnya terhadap terhadap perkara anak serta bagaimana implementasi kebijakan peran advokat dalam pendampingan perkara anak di tingkat penyelidikan dan penyidikan di kepolisisan, kejaksaan dan pengadilan Negeri Kuningan. Methode penelitian yang digunakan oleh penyusun dalam pembahasan penelitian ini adalah methode Evaluatif Analisis, yaitu suatu methode mengumpulkan dan menyajikan data yang diperoleh untuk menganalisis keadaan yang sebenarnya dan selanjutnya dilakukan analisis rasional berdasarkan acuan yuridis melalui penelitian kepustakaan dan penelitian lapangan. Hasil Penelitian ini yaitu Pertama,.Pasal 23 ayat (1) Undang Undang nomor 11 Tahun 2012 Tentang Sistem Peradilan Pidana Anak, Perda Kabupaten Kuningan Pasal 17 hurp (b) No.15 Tahun 2003 Tentang Penyelenggaraan Perlindungan Anak .Kedua, Implementasi peran advokat dalam pendampingan perkara anak di Indonesia belum dilaksanakan dengan maksimal baik di kepolisian, kejaksaan maupun pengadilan hal ini karena faktor faktor sebagai berikut yaitu Faktor Peratuan Perundang Undangan, Faktor Aparat Hukum dan Faktor Kesadaran Masyarakat (Budaya Hukum). Oleh sebab itu perlu adanya rekontruksi peningkatan kesadaran melalui
\end{abstract}


pendidikan, pelatihan dan sosialisasi terhadap penegak hukum perkara anak maupun terhadap budaya hukum masyarakat tentang kewajiban pendampingan advokat sehinga tujuan keadilan perlindungan anak dapat terpenuhi.

Kata Kunci : Advokat., Perlindungan Anak, Keadilan

\section{INTRODUCTION}

Every citizen has the same rights before the law as declared in the 1945 Constitution of the Republic of Indonesia Article 27 paragraph (1) that "All citizens together with their position in law and government must uphold the law and government with no exception". Meanwhile, Article 28 D paragraph 1 states "Everyone has the right to recognition, guarantee, protection and legal certainty as well as equal treatment before the law". Based on Article 27 paragraph (1) and Article $28 \mathrm{D}$ paragraph 1 , the equality before the law in the State of Law can be understood that everyone has the same and balanced position and there is no exception so that justice and truth in achieving the objectives of the State of law can be achieved.

Article 1 paragraph (1) of Advocate Law Number 18 of 2003 concerning Advocates explains that an advocate is a person whose profession is providing legal services both inside and outside the court that meets the requirements based on legislations. The legal services that can be provided include legal consultations, legal assistance, representation, defense, and other legal actions for the client's legal interests. The application of the presumption of innocent principle towards client in criminal justice system must be upheld as the protection of the client's human rights, as stated in Article 8 of Law Number 48 of 2009 that everyone suspected, arrested, detained, prosecuted or tried in court must be considered innocent before the court declares him guilty and has obtained permanent legal force. Advocate profession is a noble profession and is the oldest one besides medical profession. Its mission is a call to help people in need. Advocate profession exists because people need services provided by a professional who has legal competence. Thus, that is an important factor related to this profession, namely a belief factor ${ }^{1}$. The legal provision relating to advocate position in investigation process is explained in Article 50 - Article 74 of the Criminal Code. This provision gives the suspect the right to be treated equally in law enforcement process. This is in line with the principle of equality before the law that everyone has the same position in law and government. Article 50-Article 74 of the Criminal Code will be properly implemented if there is an assistance provided by advocates as legal counsels. For this reason, the position of an advocate is one of the pillars in terms of the suspect's rights in law enforcement process. An advocate should defend the suspect's rights in accordance with the law since the suspect will be attacked thoroughly by the prosecutors to be charged as a criminal offense based on the results of BAP. ${ }^{2}$

The presence of advocate in criminal justice system is included as legal apparatus group that has a balancing function in controlling criminal justice process towards clients as suspects, defendants or even as prisoners who still have the right to file legal remedies and whether the process is in accordance with the legislation or not. Advocate or Legal Consultant is an important component in criminal justice system in order to establish a fast, simple, honest as well as authoritative judiciary. Thus, the presence of advocate or legal consultant outside the criminal justice system is very detrimental to justice seekers and the working mechanism of the criminal justice system itself. ${ }^{3}$

Law Number 39 of 1999 concerning Human Rights also specifies children's rights in Articles 55 to 66. Based on these articles, children have the basic rights even when

\footnotetext{
${ }^{1}$ Frans Hendra Winarta, 2009,. Pro Bono Publico, Hak Konstitusional Fakir Miskin Untuk Memperoleh Bantuan Hukum, Gramedia Pustaka Utama, Jakarta, pp..2

2 Ahmad Rifa'i, Kedudukan dan Peran Advokat dalam Proses Penyelesaian Perkara Pidana, Jurnal Al-Ihkam, Vol.II No.2 Desember 2008, pp.317.

3 Romli Atmasasmita, Sistem Peradilan Pidana Kontemporer, Kencana Prenadamedia Group, Jakarta, 2011, pp,18
} 
they were still in the womb. So, when a child commits an act that violates law or is often said to be in conflict with law, the child has a special right. He should not be punished for life and imprisonment of a child is the last choice that should be taken. Other regulations are Law Number 1 of 2016 concerning the third amendment to Law Number 23 of 2002 and Law Number 35 of 2014 concerning Child Protection. Various kinds of bullying occurred in children include: 1) Physical Bullying, in the form of fighting, hitting, physical sanctions, and push-up; 2) Verbal Bullying, in the form of mocking, impolite words, dirty words, and prosecuting; and 3) Mental/Psychological Bullying, in the form of firing, cheating, isolating and intimidating. ${ }^{4}$

The paradigm shift happens in criminal law regarding justice. Originally, the criminal law justice used was restributive justice in which the settlement of criminal cases is done by emphasizing justice on retaliation, problem solving, and children as objects. The unbalanced law then leads to restitution justice in which the settlement of criminal cases is done by emphasizing justice on compensation. The current Law Number 11 of 2012 also applies restitution justice in which the settlement of criminal cases is done by emphasizing justice on compensation. ${ }^{5}$

Child protection is an effort to protect children so that they can run their rights and obligations. Child protection law is stated in legislation (written or unwritten) that guarantees them to run their rights and obligations. ${ }^{6}$ Children's rights protection is an interesting topic to discuss in law enforcement in Indonesia. ${ }^{7}$ Many researches on child protection have been conducted, but research on advocates' rights in assisting child cases has not been widely conducted. Therefore, this research is considered

\footnotetext{
${ }^{4}$ Muhammad, Aspek Pelindungan Anak dalam Tindak Kekerasan (Bullying) Terhadap Siswa Korban Kekerasan di Sekolah, Jurnal Dinamika Hukum Vol. 9 No. 3 September 2009, pp.230-236

5 Marlina, Peradilan Pidana anak di Indonesia, Rafika Aditama;Bandung,2009, pp..25.

${ }^{6}$ Arif Gosita, Masalah Perlindungan Anak ,Akademi Pressindo, Jakarta, 1989, pp.. 52-53

${ }^{7}$ Laurensius Arliman S, Partisifasi Masyarakat didalam perlidungan Anak yang Berkelanjutan Sebagai Bentuk Kesadaran Hukum, PADJADJARAN Jurnal Ilmu Hukum Volume 3 No.2 Tahun 2016, pp..310-329
}

important to be conducted to support child protection efforts in Indonesia, especially concerning on advocates' roles and rights in assisting child cases. Based on the description above, the issues raised in this research are formulated into the following questions: What are the advocates' rights in assisting child cases at this time? What is the implementation of advocates' rights in assisting child cases in Kuningan District? How is the reconstruction of advocates' rights in assisting child cases in Kuningan District?

\section{METHOD}

The method used in this research was the Evaluative Analysis method, which is a method of collecting and presenting the obtained data to analyze actual situation and subsequently carry out rational analysis based on juridical references through library and field research. The legal research method, according to Soerjono Soekanto, is a scientific activity to study a certain number of legal phenomena by analyzing them based on certain methods, systematics and thinking. ${ }^{8}$ After the data were collected through observation, questionnaires and interviews, qualitative data processing and analysis was carried out in accordance with the nature of this research, namely Evaluative Analysis.

\section{RESULTS AND DISCUSSION \\ The Regulations of Advocate Rights in Child Criminal Cases \\ The Regulations Based on International Conventions \\ On November 20, 1959, the general} assembly of the United Nations (UN) has ratified the declaration on children's rights. In the preamble of this declaration, it is implied that human being is obliged to provide the best for children. This is the realization of child protection principles that have been universally conceived for a long time so that it should be applied throughout the world for the law enforcement of child protection. The Declaration contains 10 principles on children's rights, as follows: ${ }^{9}$

\footnotetext{
8 Soerjono Soekanto, 1984, Pengantar Penelitian, Cet.2007, Jakarta : UI Press, pp.5

${ }_{9}^{9}$ Maidin Gultom, Perlindungan Hukum Terhadap Anak dalam Sistem Peradilan Pidana Anak Di Indonesia, Bandung, Refika Aditama, 2014, pp.54-56
} 
1. Children have the right to possess all their rights in accordance with the provisions contained in this declaration. Every child's rights, without exception, must be guaranteed without any discrimination, such as ethnicity, skin color, gender, language or other status.

2. Children have the right to special protection and should have the opportunity guaranteed by law and other means, so that they are able to develop themselves physically, psychologically, morally, spiritually, and socially in a right way according to their freedom and dignity. In terms of law, the best interests of the child should be the main consideration.

3. Children from birth have the right to name and nationality.

4. Children have the right, and must be guaranteed socially, to grow and develop in a healthy way. Thus, both before and after birth, there must be special care and protection for the child and his mother. Children have the right to get adequate nutrition, housing, recreation, and health services.

5. Children with disabilities or special needs, mental and weak social position due to certain conditions should get education, care, and special treatment.

6. In order for the child's personality to grow optimally and harmoniously, he needs love and understanding. As far as possible, he must be raised under care and responsibility of his own parents, and must be endeavored to be in an atmosphere of compassion, physically and mentally healthy. 5 (five) years old children are not allowed to be separated from their mothers. Authorized communities and governments are obliged to provide special care to children who do not have families and children who come from poor family. Then, it is hoped that the government or other parties provide financial assistance to them.

7. Children have the right to get free education at least at the level of basic education. They should be able to get education that can increase their general knowledge on the basis of equal opportunities to develop their abilities, personal opinions, and their moral and social responsibilities, so that they can become useful society members. Children's interests should be used as guidelines by those who are responsible for the education in which the very first responsibility lies on their parents. Children should have the opportunity to freely play which are then directed to educational purposes. Society and the authorized government should carry out this order.

8. Under any circumstances, children should be prioritized in receiving protection and help.

9. Children should be protected from any kind of violence and exploitation. They cannot be the subject of trade. They cannot work before a certain age. They cannot be involved in works that can harm their health and education, or which can affect their growth, spirit and morals.

10. Children should be protected from actions leading to social, religion or other forms of discrimination.

Looking at the development history, today's world community seems to be indebted to Eglantynee Jebb, the founder of Save the Children Fund (an international non-governmental organization working for child protection). He, after witnessing with his own eyes, took care of child refugees in Balkan as a result of World War I, and then drafted a Children's Charter in 1923. The Convention began in 1923 by Eglantynee Jebb. The draft of the children's charter that he made was: "I believe that we should demand certain rights for children and fight for universal recognition." 10

The history of the development of children's rights gave birth to some international conventions, namely: ${ }^{11}$

1. In 1923, children's rights were approved by Save the Children Union.

2. In 1924, the right approved by the League of Nation was an international effort as a result of experiences with children suffering from war in several countries.

10

http://repository.usu.ac.id/bitstream/123456789/1572/3/hu kum-edy.pdf.txt diakses Desember 2017, acessted 2 July 2018

11 Mochtar Kusumaatmadja, Pengantar Hukum Internasional Buku I, Binacipta, Bandung, 1997, pp.107 
3. In 1948, the United Nation (UN) General Assembly legitimized the Universal Declaration on human rights in which children's rights are implicitly included even though many people think that children's special needs need to be compiled in a separate document.

4. In 1959, the UN General Assembly legitimized the second Declaration on children's rights and UN Human Rights group began working on the concept of children's rights convention.

5. In 1962, two international covenants were made; the first covenant is on civil and political rights and the second covenant is on economic, social and cultural rights. The two covenants bind the ratifying country. In 1976, the State was obliged to respect human rights owned by individuals. The old declaration was only an appeal of morality and ethics because it clearly did not have the legal binding capacity for each country to carry it out.

6. In 1979, when the Polish State submitted a draft on the children's rights convention, ten items from the declaration were widely published.

7. On November 20,1989, the Convention on children's right with 54 Articles was approved by the United Nations General Assembly and declared to be valid from that time on and the Convention on children's right has legal force for the ratifying country.

The obligation to provide legal assistance to children at the international convention on November 20, 1989 is declared in article 37 point (d), that: "Every child deprived of his or her liberty should have the right to prompt access to legal and other appropriate assistance as well as the right to challenge the legality of the deprivation of his or her liberty before a court or other competent, independent and impartial authority, and to a prompt decision on any such action"

\section{The Regulations Based on Law Number 11 of 2012 concerning Child Criminal Justice System}

Child protection is carried out based on Pancasila and the 1945 Constitution of the Republic of Indonesia as well as the basic principles of the Convention on children's rights which include the principle of nondiscrimination, the principle of the best interests for children, the principle of the right to life, survival and development, and the principle of respect for children's opinions.

Advocates' rights in legal assistance are generally regulated in Article 69 to Article 73 of Law Number 8 of 1981 concerning the Criminal Code (KUHAP), namely:

a. Legal consultant has the right to contact the suspect from the time he is arrested or detained at all levels of investigation based on the procedures set out in this law (Article 69 of KUHAP);

b. Legal consultant, as declared in Article 69, has the right to contact and talk to the suspect at all levels of investigation and at all times for the purpose of his case defense (Article 70 paragraph (1) KUHAP);

c. Legal consultant has the right to send and receive letters from the suspect whenever he wishes (Article 73 of KUHAP).

Moreover, in Law Number 18 of 2003 concerning advocates, advocates' rights in legal assistance are stated in Article 17, 19 paragraph (2) and Article 21 paragraph (1), namely:

a. Advocates have the right to obtain information, data, and other documents both from Government agencies and other parties related to the information needed to defend their Clients in accordance with legislations (Article 17)

b. Advocates have the right regarding the confidentiality of their relationship with their Client, including the protection of their files and documents against confiscation or inspection and protection of wiretapping of their electronic communications (Article 19 paragraph (2));

c. Advocates have the right to receive Honorarium for the legal services given to their clients (Article 21 paragraph (1)).

The legal provision relating to advocate position in investigation process is explained in Article 50 - Article 74 of the Criminal Code. This provision gives the suspect the right to be treated equally in law enforcement process. This is in line with the principle of equality before the law that everyone has the same position in law and government. Article 50Article 74 of the Criminal Code will be properly implemented if there is an assistance 
provided by advocates as legal counsels. For this reason, the position of an advocate is one of the pillars in terms of the suspect's rights in law enforcement process. An advocate should defend the suspect's rights in accordance with the law since the suspect will be attacked thoroughly by the prosecutors to be charged as a criminal offense based on the results of BAP. ${ }^{12}$

One of advocate's rights in assisting child cases in Law Number 11 of 2012 concerning Child Criminal Justice System is declared in Article 23 paragraph (1), that: "In each level of investigation, the child should be given legal assistance and accompanied by a community advisor or other parties in accordance with the legislation".

Meanwhile, the definition of legal assistance, according to Article 1 paragraph (1) of Law Number 16 of 2011 concerning Legal Assistance, is a legal service provided by Legal Assistance Body to Legal Assistance Recipients. In addition, Article 1 paragraph (3) declares that Legal Assistance is provided by a legal assistance body or community organization that provides Legal Assistance services based on legislation. On the other hand, advocate is a profession that has the right to conduct legal assistance services both litigation and non-litigation.

The history of legal assistance has been around for a long time, both internationally and in Indonesia, which proves that the role of legal assistance is very important as part of law enforcement process. Legal assistance exists due to the low awareness of the society regarding legal rights, other processes or technical matters, including information about the right to use legal assistance services that can be accessed freely for people who cannot afford it. All citizens with no exception have the right to get legal assistance services in their cases by litigation or non-litigation. It is a form of state's responsibility in order to protect its citizens as mandated by article 27 paragraph (1) of the 1945 Constitution which was passed down to Law Number 16 of 2011 concerning Legal Assistance. ${ }^{13}$

\footnotetext{
${ }^{12}$ Ahmad Rifa'i, Kedudukan dan Peran Advokat dalam Proses Penyelesaian Perkara Pidana, Jurnal Al-Ihkam, Vol.II No.2 Desember 2008, pp.317.

${ }^{13}$ Diding Rahmat, Eksistensi Lembaga Bantuan Hukum (Lbh) Cirebon Dalam Pendampingan Perkara Pidana Di Pengadilan Negeri Cirebon, Jurnal Unifikasi, Vol. 03 Nomor 01 Januari 2016, pp.89
}

Legal assistance program is a program that provides litigation and non-litigation legal services provided by legal assistance body to legal assistance recipients. The principle of its implementation should be based on the principles of justice, equality before the law, openness, efficiency and effectiveness as well as accountability. Kuningan District is one of the districts in West Java that has a legal assistance program. The program is collaboration between the Kuningan District Regional Government, the Court, the Prosecutor's Office, Kuningan Police and an accredited Legal Assistance Organization in West Java. The program began in 2014 until now. ${ }^{14}$

Based on the description above, it is clear that the presence of advocates in assisting child cases is a constitutional obligation as declared in Article 23 paragraph (1) of Law Number 11 of 2012 concerning Child Criminal Justice System.

\section{The Regulations Based on Kuningan District Regional Regulation Number 15 of 2013 concerning Implementation of Child Protection}

The Regional Regulation specifically regulates the need for legal assistance in child cases so that child protection can be well implemented. Article 17 states that every child whose liberty is deprived has the right to:

a. Get humane treatment and his placement should be separated from adults;

b. Obtain legal assistance or other assistance in all level of investigation based on legislation;

c. Self-defense and get justice in an objective and impartial child court and in a closed session for public.

d. Every child who is a victim or suspect of sexual violence or who is dealing with the law has the right to be kept confidential.

Based on the Article above, the regulation of advocates' rights in child protection in Kuningan District already has a good legal basis, which is found in Article 17 Point (b).

\footnotetext{
${ }^{14}$ Diding Rahmat, Implementasi Kebijakan Program Bantuan Hukum Bagi Masyarakat Tidak Mampu Di Kabupaten Kuningan, Jurnal Unifikasi, Vol. 04 Nomor 01 Januari 2017,pp.39
} 


\section{The Implementation of Advocate Rights in Assisting Child Cases}

The Commissioner of Indonesian Child Protection Commission (KPAI), Jasa Putra, said that children's problem in Indonesia is still high. In the last five years, more than 8,200 cases of children against law occurred. Jasa declared the reports submitted to KPAI for the 2011-2016 period showed that there were around 23,800 child cases in nine clusters. $\mathrm{He}$ explained that there were three groups with the highest problems, namely children against law, alternative child care, and education problems. ${ }^{15}$

Table 1. Number of Children against Law $(\mathrm{ABH})$ at Kuningan Police Station

\begin{tabular}{|ccc|}
\hline No. & Year & Amount \\
\hline 1 & 2016 & 211 \\
\hline 2 & $\begin{array}{c}\text { January to } \\
\text { April }\end{array}$ & 102 \\
\hline
\end{tabular}

Source: Kuningan Police Station

Advocates should always maintain the honor and dignity of their profession. They act as an introduction to the administration of justice. The obligation of an advocate to his clients should include the following: ${ }^{16}$

a) Providing advice to clients regarding their legal rights and responsibilities, so that the operation of the system has relevance to the rights and obligations of their clients.

b) Assisting client in a right way and doing legal efforts to protect the interests of his clients.

c) Defending clients in court or in dealing with government agencies in an appropriate way.

Based on the description above, the presence of advocates in assisting public and child cases is very much needed so that the transparency of justice can go well since justice is the root of all national problems, especially in law enforcement process.

15 https://nasional.tempo.co/read/893559/kpai-ada-lebihdari-8-200-kasus-anak-berhadapan-dengan-hukum, downloaded on June 20, 2018

16 Artidjo Alkostar Dalam Disertasi DR.H.D.Junaedi, Rekontruksi Perlindungan Hukum Advokat Sebagai penegak Hukum Dalam Mewujudkan Keadilan Berbasis Hukum Progresif, Semarang: PDIH Unissula, 2015, pp, 70.
According to Soedikno Mertokoesoemo, Justice consists of three types, namely:

1. Commutative Justice - Justice in determining equal results;

2. Distributive Justice - Justice in determining results obtained based on merit;

3. Legalist Justice - Justice in treating the Government; do not only assess the Government's policies from negative side, but also provide the best solutions. ${ }^{17}$

Dignified justice is a legal theory which is known in English literature as the concept of legal theory, jurisprudence, or philosophy of law and knowledge of the substantive law of a legal system. The scope of a dignified justice theory is not only the disclosure of dimensions that are abstract from the rules and principles of valid law, but it also reveals all rules and principles of the valid law in a legal system. In this case, the legal system is the positive Indonesian legal system or the legal system which is based on Pancasila. That is why the dignified justice refers to a legal theory based on Pancasila. The dignified justice theory does not only pay attention to the legal foundation layer that appears on the surface of a legal system, but it also attempts to trace and uncover the layers of legal foundations that lie below the surface of the visible legal system. The dignified justice theory, in accordance with its philosophical characteristics, tries to explore old values or foundations beneath the surface of the new legal system foundation, as well as breaking down the colonial foundation. The foundation that has existed for a long time in the soul of the nation is seen as a bottom-line of a legal system where the entire contents of the building system are put in place and function to pursue the goal of justice. ${ }^{18}$

The legal system, based on L.M. Freedman theory, consists of three components, namely: legal structure, legal substance, and legal culture components. The legal structure is the torso, framework, or the eternal form of a system. The legal substance is the actual rules and norms used by institutions, and can be in the form of behavior of the actors observed in the system. Then, the legal culture is the ideas, attitudes, beliefs, hopes and opinions about the

\footnotetext{
${ }^{17}$ Soedikno Mertokoesoemo 1985, Hukum Acara Perdata Indonesia, Liberty, Yogyakarta, pp.70

${ }^{18}$ Teguh Prasetyo, 2015, Keadilan Bermartabat Persfektif Teori Hukum, Nusa media, Badung, pp. 61
} 
law. In its development, Freedman adds the fourth component, which he calls as the legal impact component. The legal impact is the impact of a legal decision which becomes an object of research by the researcher. ${ }^{19}$ In relation to legal culture, according to Roger Cotterrell, the concept of legal culture explains the diversity of ideas about law that exist in society and their position in social order. These ideas explain legal practices, citizens' attitudes toward law and their willingness and unwillingness to file cases and to explain thoughts and behavior outside the practice and specific forms of discourse related to legal institutions. Thus, variations in legal culture may be able to explain a lot about different ways in which legal institutions that appear to be the same can function in different societies. ${ }^{20}$

Based on the discussion above, there are several factors which are maximal or not maximal regarding advocates' rights in assisting child cases based on law enforcement theory by Soerjono Soekanto, namely: ${ }^{21}$

1. Legal factors or legislation

2. Law Enforcement factors, namely parties who establish or apply the law

3. Facilities factors, namely facilities that support law enforcement

4. Society factors, namely environment in which the law is applied.

The explanation of those factors is presented below.

\section{Legal Factors or Legislation}

This factor is already maximal because there is Law Number 11 of 2012 concerning Child Criminal Justice System, especially Article 23 Paragraph (1) which describes advocate's right to provide legal assistance in child cases. Yet, based on the analysis, the weakness of this legislation is due to the lack of socialization or the absence of implementing rules or additional rules relating to Article 23 Paragraph (1), such as government regulations, police

\footnotetext{
${ }^{19}$ Suwari Akhmaddhian, Penegakan Hukum Lingkungan Dan Pengaruhnya Terhadap Pertumbuhan Ekonomi Di Indonesia (Studi Kebakaran Hutan Tahun 2015), Jurnal Unifikasi Vol.3 Nomor 1 Januari 2016, Kuningan: FH Universitas Kuningan, pp..7

20 Mochtar Kusumaatmadja, 1986, Fungsi dan Perkembangan Hukum dalam Pembangunan Nasional, Bandung: Binacipta, pp. 11

${ }^{21}$ Soerjono Soekanto, Faktor-faktor yang Mempengaruhi Penegakan Hukum,PT. Raja Grafindo Persada, Jakarta, 1983,pp..5
}

regulations, ministerial regulations, regional regulations, etc., so that this regulation is implemented differently by law enforcement agencies and society.

\section{Law Enforcement Factors}

Law enforcement factors are the next factor consisting of police officers, prosecutors, lawyers, judges, and correctional institution officials or often referred to as Panca Wangsa Keadilan. In law enforcement factors, in many cases, there is no synchronization of understanding about advocates' rights in assisting child cases. They do not have understanding about Article 23 Paragraph 1 of Law Number 11 of 2012 concerning Child Criminal Justice System. Thus, both the lawyers and the law apparatus do not consider the need for advocate's obligation in assisting child cases either at the level of investigation in Police station, pre-prosecution or prosecution at the Prosecutor's level, at the trial level which is the domain of Judges, up to the correctional institution level by the Correctional Institution officials.

From the results of the analysis, it was found that some factors causing child cases are not assisted by advocates are:

a. The legal apparatus does not understand Article 23 paragraph 1 of Law Number 11 of 2012 concerning Child Criminal Justice System. They are always guided by the Criminal Code (KUHAP) which requires advocate if the legal threat is 5 years and above. In fact, child cases are Lex Specialis's cases in which based on the legislation, it should be assisted by an advocate and even if it is forced to be done, this will result on decision cancellation and the child should be released from punishment. $^{22}$

b. The view of the high cost of advocates from law enforcement and society so that law enforcement officials tend not to find advocates in handling child cases. Meanwhile, with Law Number 16 of 2011 concerning Legal Assistance, the state has prepared budget through APBN so that poor people can get free legal assistance. Thus, socialization needs to be done at the level of legal apparatus to be able to cooperate with legal assistance body in

\footnotetext{
${ }^{22}$ Interview with Unit PPA Polres Kuningan and P2TP2A Kab Kuningan on 21 March 2018
} 
accordance with the legal assistance law and do not have to worry about the advocates' fees. ${ }^{23}$

c. There are a lack number of advocates so that they think that child cases assistance does not need to be done by an advocate, involving social organizations which have a child protection program is enough. ${ }^{24}$

d. Low public awareness on the importance of advocates in assisting criminal cases, especially child cases.

\section{Facilities and Infrastructure Factors}

Facilities and infrastructure factors that support law enforcement include child investigation rooms, child detention rooms in police station, and child correctional institutions. Based on the data, Kuningan district does not have child detention rooms either in police or correctional institutions. This affects the law enforcement of child cases which is not in accordance with the principles and objectives of child protection stated in international conventions or legislation.

\section{Cultural factors and community legal awareness}

The low legal culture of the society, which is due to lack of information and understanding of children's rights, is one of the reasons why the law enforcement for children is not going well. One of the efforts done to improve legal culture and legal awareness is through education and socialization of various legislations. Besides, one effective way that can be done is legal counseling. ${ }^{25}$ Therefore, there is a need for training, socialization and legal counseling regarding the advocates' obligations in assisting child cases.

\section{Reconstruction of Advocate's Rights Policy in Assisting Child Criminal Cases Scientifically, the term reconstruction means the formulation or rearrangement of a concept. In a physical}

\footnotetext{
23 Interview with Mr. H.Indra Sahnun Lubis Presiden Kongres Advokat Indonesia on 24 August 2017

${ }^{24}$ Interview wih Mr. Agus Amaldo Advokat on LBH Cirebon date 8 June 2018

25 Iman Pasu Marganda Hadiarto Purba, Penguatan budaya hukum masyarakat untuk menghasilkan kewarganegaraan transformatif, Jurnal Civics Volume 14 Nomor 2, Oktober 2017,pp.150
}

sense, reconstruction is the rebuilding of all institutional infrastructure and facilities in the post-disaster area, both at the government and community levels with the main objectives of growing and developing economic activities, socio-cultural, upholding law, and the rise of community participation in all aspects of life in the postdisaster area. ${ }^{26}$ Meanwhile, according to BN Marbun, reconstruction is the return of something to its original place; Arranging or redrawing of existing materials and rearranging as they were or the original form. ${ }^{27}$

Re-formulation or re-drafting of advocate policy in assisting criminal cases based on value of justice should be seen from the law enforcement factors above. In this case, it can be concluded that legal factors and legal apparatus factors should be made as factors that should be reconstructed so that the value of justice in law enforcement especially in child cases can be realized. This is a reflection of the results of the research that there is a lack of synchronization of understanding between law enforcement officials towards the interpretation of Law on child criminal justice system Article 23 Paragraph (1) which requires assistance from advocates in child cases. When there is a reconstruction of the legislation, it should result in the construction of value of justice obtained by children dealing with law.

\section{CONCLUSION}

Based on the discussion above, it can be concluded that:

1. In general, the regulation of advocate's rights is regulated in Law Number 8 of 1981 concerning Criminal Code (KUHAP), Law Number 18 of 2003 concerning Advocates, and Law Number 16 of 2011 concerning Legal Assistance. Specifically, the regulation of advocate's rights in assisting child cases is declared in Article 37 Point (d) of the International Convention on Children's Rights. Meanwhile, in

\footnotetext{
26 www.hidupbersamabencana.com, downloaded on 4 February 2018

27 B.N. Marbun, 1996, Kamus Politik, Pustaka Sinar Harapan, Jakarta, pp..469
} 
Indonesia, it is regulated in Article 23 paragraph (1) of Law Number 11 of 2012 concerning Child Criminal Justice System, and for Kuningan District, it is regulated in the Kuningan District Regional Regulation Article 17 Point (b) Number 15 of 2003 concerning the Implementation of Child Protection.

2. The implementation of child cases assistance in the police, prosecutor's office and court has not run optimally due to the following factors, namely legislative factors, law enforcement factors, facilities and infrastructure factors, legal culture factors and public awareness. Of the five factors, the legal apparatus factor becomes the most influential factor of the absence of legal assistance in child cases by advocates. This is due to incomprehension of Article 23 Paragraph (1) of Law Number 11 of 2012 concerning Child Criminal Justice System and the Kuningan District Regulation Article 17 Point (b) Number 15 of 2003 concerning the Implementation of Child Protection which requires an advocate to provide legal assistance in child cases.

3. In terms of reconstruction of advocate's rights policy in assisting child cases, namely Article 23 Paragraph (1), a policy regarding explanation of the law in the form of Government Regulations, Ministerial Regulations or so on which provides a more specific and assertive explanation regarding the obligation to provide legal assistance from advocates in child cases is very much needed, so that the value of justice (Restorative Justice) in child cases can be in accordance with the purpose of child protection. In addition, there is a need for training, socialization and legal counseling to legal apparatus and society regarding the advocates' obligations in assisting child cases.

\section{SUGGESTION}

The suggestions that can be provided based on the results of this research are as follows:

1. Legislations concerning the advocates' rights in assisting child cases should be implemented by the legal apparatus, namely the police at the stage of investigation, prosecutors at the prosecution stage, and judges at the trial.
2. Legal apparatus should be given socialization and training concerning the advocates' obligations in assisting child cases based on Article 23 Paragraph (1) of Law Number 11 of 2012 concerning Child Criminal Justice System so that the advocates' right in assisting child cases can be optimally implemented.

3. In terms of reconstruction of advocate's rights policy in assisting child cases, a policy regarding explanation of the law in the form of Government Regulations or Ministerial Regulations which provides a more specific and assertive explanation regarding the obligation to provide legal assistance from advocates in child cases is very much needed.

Books

\section{REFERENCES}

Arif Gosita (1989). Masalah Perlindungan Anak, Akademi Pressindo, Jakarta, 1989

Artidjo Alkostar Dalam Disertasi DR.H.D.Junaedi,(2015),Rekontruksi Perlindungan Hukum Advokat Sebagai penegak Hukum Dalam Mewujudkan Keadilan Berbasis Hukum Progresif, Semarang: PDIH Unissula.

B.N. Marbun, (1996), Kamus Politik, Pustaka Sinar Harapan, Jakarta

Frans Hendra Winarta , 2009,.Pro Bono Publico, Hak Konstitusional Fakir Miskin Untuk Memperoleh Bantuan Hukum, Gramedia Pustaka Utama, Jakarta

Marlina, (2009) ,Peradilan Pidana anak di Indonesia, Rafika Aditama;Bandung,

Maidin Gultom. (2014)., Perlindungan Hukum Terhadap Anak dalam Sistem Peradilan Pidana Anak Di Indonesia, Bandung, Refika Aditama, 2014

Mochtar Kusumaatmadja, (1986). Fungsi dan Perkembangan Hukum dalam Pembangunan Nasional, Bandung: Binacipta

Mochtar Kusumaatmadja, (1997). Pengantar Hukum Internasional Buku I, Binacipta, Bandung, 1997

Romli Atmasasmita, (2011). Sistem Peradilan Pidana Kontemporer, Kencana Prenadamedia Group, Jakarta.

Soerjono Soekanto, (1983). Faktor-faktor yang Mempengaruhi Penegakan Hukum,PT. Raja Grafindo Persada, Jakarta. 
Teguh Prasetyo . (2015), Keadilan Bermartabat Persfektif Teori Hukum, Nusa media, Badung

\section{Journals}

Ahmad Rifa'I . (2008). Kedudukan dan Peran Advokat dalam Proses Penyelesaian Perkara Pidana, Jurnal Al-Ihkam, Vol.II No.2 Desember 2008.

Diding Rahmat. (2016). Eksistensi Lembaga Bantuan Hukum (LBH) Cirebon Dalam Pendampingan Perkara Pidana Di Pengadilan Negeri Cirebon, Jurnal Unifikasi, Vol. 03 Nomor 01 Januari 2016

Diding Rahmat. (2017). Implementasi Kebijakan Program Bantuan Hukum Bagi Masyarakat Tidak Mampu Di Kabupaten Kuningan, Jurnal Unifikasi, Vol. 04 Nomor 01 Januari 2017

Iman Pasu Marganda Hadiarto Purba. (2017). Penguatan budaya hukum masyarakat untuk menghasilkan kewarganegaraan transformatif, Jurnal Civics Volume 14 Nomor 2, Oktober 2017

Muhammad, Aspek Pelindungan Anak dalam Tindak Kekerasan (Bullying) Terhadap Siswa Korban Kekerasan di Sekolah, Jurnal Dinamika Hukum Vol. 9 No. 3 September 2009

Laurensius Arliman S. (2017). Partisifasi Masyarakat didalam perlidungan Anak yang Berkelanjutan Sebagai Bentuk Kesadaran Hukum, PADJADJARAN Jurnal Ilmu Hukum Volume 3 No.2 Tahun 2017

Suwari Akhmaddhian (2016). Penegakan Hukum Lingkungan Dan Pengaruhnya Terhadap Pertumbuhan Ekonomi Di Indonesia (Studi Kebakaran Hutan Tahun 2015), Jurnal Unifikasi Vol.3 Nomor 1 Januari 2016, Kuningan: FH Universitas Kuningan 